IRSH 49 (2004), pp. 40I-434 DOI: I0.10I7/S002085900400I737

(C) 2004 Internationaal Instituut voor Sociale Geschiedenis

\title{
“To Fight the Battles of the Workers": The Emergence of Pro-strike Publications in Early Twentieth-Century South Africa*
}

\author{
WESSEL P. VISSER
}

Summary: The role of pro-strike newspapers during the first two decades of labour history in twentieth-century South Africa, an era of intense industrial strife, has not been researched in depth by labour historians. This article examines the emergence of a pro-strike press and examines its position on various strike issues. It served as a conduit for workers' grievances during industrial disputes, such as the strikes of I9II, I9I3, I9I4, and I922. Such papers were often also the only means of communication between the strike committee and the strikers themselves. The article also discusses the extent to which such publications might have impacted upon their readership and actual strike action. It concludes that pro-strike literature in essence reflects a "white-labour" discourse and a fusion of the class and racial consciousness that prevailed among the white working class of South Africa.

\section{INTRODUCTION}

Internationally the first two decades of the twentieth century were an era of intense industrial strife, and no problem loomed as large as the labour question. The scope and gravity of strikes were increasing. Industrial enterprises became concentrated in huge businesses, and those who ran them refused to make agreements that would allow the unions to curtail their freedom. Without exception, these business enterprises were hostile to the principle of collective bargaining. Thus, action by the workers was tending to become political just at the time when the nature of the state was changing. As the state became more and more of an employer itself, with numerous officials and workers of its own, governments had to decide whether they should stand by while strikes spread to vital sectors of the nation's economy. A state whose railwaymen, postmen, and miners were

* I am deeply indebted to Jon Hyslop of WISER and Lucien van der Walt of the Sociology Department at the University of the Witwatersrand, for their sound comments, advice, and constructive criticism of this article. 
on strike was threatened with paralysis and could therefore ill afford to stand aloof from industrial disputes. ${ }^{\mathrm{I}}$

Similar to the situation in the rest of the industrial world in this period, South African labour history is characterized as an era of political turmoil as well as of large-scale and serious endemic industrial unrest which culminated in a number of major strikes. This industrial strife formed part of a cathartic process in which the relationship between capital and the state and its subjects in the field of labour took shape. From I 902 onwards, strikes of varying scope began to appear in private-sector industries such as printing, mining, building, food, and banking, as well as in public sector institutions such as municipalities, railways, and harbours. A few prominent strikes, predominantly characterized by violent confrontations between strikers and government forces, also occurred in this period. They were the I 907 miners' strike, the tramways and printers' strikes of I9II, the I9I 3 miners' strike, the I9I4 general strike, and the so-called Rand Revolt of I922. Most of these strikes took place on the Witwatersrand, the industrial hub of South Africa, with Johannesburg as central locus of gravity. $^{2}$

Particularly in mining, the largest South African industry, matters such as regulations and safety, miners' phthisis, workmen's compensation, the eight-hour working day, prohibition of Sunday work, paid holiday work, minimum wages, job security, the use of scab labour during strikes, the recognition of trade unions, job reservation for whites, and the retention of job colour-bars in industry were the contentious issues in the negotiations and disputes between trade unions and employer organizations, much as they were with the Chamber of Mines. ${ }^{3}$

In Britain and elsewhere the position of the press agitating for or against strikes in periods of industrial strife is also strikingly apparent, and has drawn the attention of labour historians and sociologists. For example, numerous studies have been published on the role of newspapers and the press in general during industrial upheavals in Great Britain, ${ }^{4}$ while

I. G. Lefranc, "Strikes: Industrial Relations to I9I 4", History of the $20^{\text {th }}$ Century, I:I3 (1968), p. 344. Cf., for example, the industrial situation in Britain regarding strikes, in R.A. Leeson, Strike: A Live History I887-I97I (London, I97I).

2. See, e.g., I.L. Walker and B. Weinbren, 2000 Casualties: A History of the Trade Unions and the Labour Movement in the Union of South Africa (Johannesburg, I96I), pp. I-2I4.

3. See, e.g., A. O'Quighley, “The I9I3 and I9I4 White Workers' Strikes” (African Studies Institute Seminar, October 1978, University of the Witwatersrand), pp. 3, I 2, I 8-2 I.

4. See, e.g., M. Milne, "Strikes and Strike-Breaking in North-East England, i 8 is-44: The Attitude of the Local Press", International Review of Social History, 22 (1977), pp. 226-240; J.H. Porter, "Devon and the General Strike, 1926", International Review of Social History, 23 (1978), pp. 333-356; Conference Report, Society for the Study of Labour History Bulletin, 44 (1982), pp. 6-I 2; E. Wade, "The Miners and the Media: Themes of Newspaper Reporting”, Journal of Law and Society, I2 (1985), pp. 273-284; D.R. Green, "Lines of Conflict: Labour Disputes in London, I790-1870", International Review of Social History, 43 (1998), pp. 203-233; G. 
Charles Ruud has investigated the pivotal role that printers played in the Russian Revolution of I905.5 According to Nicholas Jones, in some strikes in Britain the presentation of the opposing arguments, both to employers and to the public, became a crucial factor in deciding the final outcome. ${ }^{6}$ Indeed, by the turn of the twentieth century, newspapers were becoming powerful propaganda media.

According to Katz, the worldwide trade-union support of general strikes, as opposed to sectional strikes, and the constant advocacy of such strikes in trade-union journals and newspapers sponsored by organized labour, had a profound impact on South Africa. Contemporary socialist and labour-sponsored newspapers, and articles published in trade-union journals also made the South African white working class aware of the efficacy of strike action, which had become more prominent in Britain, the US, Europe, and Australasia. ${ }^{7}$ In the early decades of the twentieth century, newspapers were the only real means of mass communication available to the labour movement to convey information on strike action. The effect of the soapbox oratory of the strike leaders, was usually limited to the hearing distance of the crowds they were addressing, hence the newspapers, and the pro-strike papers in particular, served as the most effective mobilizing force and conduits of communication for workers' grievances during industrial disputes between the strike committee and the strikers themselves, and between the strikers and the public at large.

With the development of mass circulation papers, initially in the West, from the end of the nineteenth century, the battle for control of the media opened in earnest. Many of the new press barons, like William Randolph Hearst in America and Max Aitken in Britain, were deeply hostile to Labour, ${ }^{8}$ and there was a similar hostility on the part of papers like The Star in South Africa. ${ }^{9}$ Therefore, all over the world Labour had to engage with the problem of how to get its side of the story told. According to Hyman et al., the establishment press is prone to convey a negative and

Crompton, "'Sheer Humbug': The Freedom of the Press and the General Strike", Twentieth Century British History, I 2 (200I), pp. 46-68.

5. See C.A. Ruud, "The Printing Press as an Agent of Political Change in Early TwentiethCentury Russia", The Russian Review, 40 (1981), pp. 378-395.

6. N. Jones, Strikes and the Media: Communications and Conflict (Oxford, I986), p. I.

7. E.N. Katz, A Trade Union Aristocracy: A History of White Workers in the Transvaal and the General Strike of 1913 (Johannesburg, 1976), pp. 423, 457. See, for example, predictions of workers' discontent that could develop into general strikes in Voice of Labour, 7 July i 9 I I, pp. 4-5; Ibid., I4 July i9i I, pp. 4-5, and ibid., 27 October I9I I, p. 4.

8. See A. Briggs and P. Burke, A Social History of the Media From Gutenberg to the Internet (Cambridge, 2002), ch. 6; A.J. Lee, The Origins of the Popular Press in England I855-1914 (London, I976), p. 2 I I and ch. 7.

9. See Katz, A Trade Union Aristocracy, p. 53, and The Star, I9 July i910, p. 6. In essence The Star was owned, controlled by, and served the interests of the mining capital of Johannesburg. 
distorted image of strikes and strikers, give free rein to antistrike feelings, and in their editorials reflect a built-in bias against collective action by workers $;{ }^{1 \circ}$ it therefore follows that, in response to this, special strike bulletins championing the cause of the strikers emerged as natural and logical by-products of industrial disputes. This was certainly the case during early twentieth-century strikes in South Africa, where white working-class pro-strike publications were closely involved in labour disputes between capital, labour, and the state.

And yet the important role of these publications has, to a large extent, been neglected by labour historians. ${ }^{\text {II }}$ Little thought has been given by them to the detail of how workers' ideas were formulated and transmitted. It might even be possible that Marxist-influenced historians have ignored such questions because they assume that "class-consciousness" is an unproblematic idea, rather than something that has a very situationspecific political content. Although the government appointed commissions of enquiry into the major industrial upheavals of I9I3, I9I4, and I922, these reports shed very scanty and only partial light on the existence and influence of the strike publications that were produced during these disputes. As far as newspapers were concerned, the reports of the commissions of enquiry only refer to the suspension of certain pro-strike publications. Such newspaper publications were usually charged in vaguely formulated terms with containing matter "calculated to promote disaffection or excite ill-feeling". ${ }^{12}$

This article therefore explores the role and influence of pro-strike publications on strike events between I9I 3 and I922, and is based largely on a detailed and systematic investigation into the history of the workingclass press in the period 1908 to $1924 .{ }^{\mathrm{I} 3}$ However, no South African

I0. See R. Hyman, Strikes (Basingstoke, 1989), pp. I57-1 58; P. Beharrell and G. Philo, Trade Unions and the Media (London, I977), pp. 3 I, 37, I 20, I 28; L.J. Macfarlane, The Right to Strike (Harmondsworth, I98I), pp. I40-I4I; T. Lane and K. Roberts, "A Strike Diary and the Role of the Press", in B. Barrett et al (eds), Industrial Relations and the Wider Society. Aspects of Interaction (London, 1979), p. 333. See also Voice of Labour, 9 June I9I I, p. 4.

I I. Elaine Katz's work on the I9I 3 miners' strike, A Trade Union Aristocracy, is the only study to date that partially explores the role and influence of a strike bulletin in early twentieth-century South African labour history.

I2. See, for example, Union Government Publications, Pretoria [hereafter, UG or Cd.], 55I9I 3 Union of South Africa: Report of the Witwatersrand Disturbances Commission; UG, 56I9I 3 Union of South Africa: Judicial Commission of Enquiry into Witwatersrand Disturbances June-July, 1913; Cd., 694I-I9I3 Union of South Africa: Correspondence relating to Recent Disorders on the Witwatersrand and the Employment of Regular Troops; Cd., 7348-1914 Union of South Africa: Correspondence relating to the General Strike in South Africa; and UG, 35-1922 Union of South Africa: Report of the Martial Law Inquiry Judicial Commission.

I3. See, in this regard, also, W.P. Visser, "Die Geskiedenis en Rol van Persorgane in die Politieke en Ekonomiese Mobilisasie van die Georganiseerde Arbeiderbeweging in Suid-Afrika, I9081924", (unpublished Ph.D. thesis, University of Stellenbosch, 200I). 
depository holds a complete set of any labour or socialist publication, or strike publication in particular, printed in the period concerned. There are many reasons for this. Depending on their magnitude and nature, and because of financial constraints, strikes did not all produce propaganda sheets or, at best, such sheets were short-lived. Even more established socialist and labour papers were often ephemeral affairs, hampered by financial and circulation constraints and sometimes lasting for little more than a few years.

In addition, many strike printing plants and a great deal of strike literature were seized and destroyed by police raids. Some copies of strike papers, though, were preserved in libraries and in the Central Archives Depot in Pretoria. The files of the Department of Justice were scrutinized for information on police raids on strike premises and for confiscated copies of strike literature. In this way very valuable material on the ownership, editors, printers, circulation, and distribution, as well as the contents of strike publications, was unearthed. With reference to the preserved socialist, labour, and strike papers published in concurrent cases, this article focuses on The Strike Herald, The News, the Strike Special (Witwatersrand miners' strike, I913), The Weekly Gazette, the Pretoria Strike Herald (the general strike, I9I4) and the Transvaal Post (the Rand Revolt, 1922). The pro-strike sentiments of the socialist weeklies, Voice of Labour and The International, and the labour-sponsored Worker were also investigated.

\section{THE SOUTH AFRICAN LABOUR SCENE AND PRESS BY THE TURN OF THE TWENTIETH CENTURY}

In order to comprehend the purpose and intent of pro-strike publications, the characteristics of the early labour movement in South Africa should be explained. When minerals were discovered in the interior of South Africa towards the end of the nineteenth century (diamonds in I 867 and gold in I886), the demand for labour increased because South Africa lacked the skills and technical expertise for hard-rock mining. Therefore skilled experts were recruited mainly from the British Empire and America. ${ }^{14}$

The first generation of goldminers came mainly from Cornwall and the north of England, such as Northumberland, while smaller numbers came from South Wales, Western Australia, California, and the Klondyke; groupings also came from other west European nationalities. Thus the Witwatersrand, the industrial hub of the South African economy with Johannesburg as its capital, became a cosmopolitan mining community

I4. E.N. Katz, The White Death: Silicoses on the Witwatersrand Gold Mines I886-1910 (Johannesburg, I994), pp. 49-50, 63-68, 75; J. Rowe, The Hard-Rock Men (Liverpool, 1974), pp. 43, II 4 , 206. 
and centre of trade-union activity in which British workers were the majority. ${ }^{\text {Is }}$

After the Anglo-Boer War (I899-1902) the white, predominantly English-speaking, labour force of the prewar years was augmented by demobilized British, Australian, New Zealand, and Canadian soldiers from the British armies. The infusion of the demobilized soldiers into the local labour movement introduced new ideas of labour and socialist organization. A section of workers from America brought with them the American variety of industrial unionism and syndicalism. Italian, German, and Jewish immigrants also contributed particular variations of socialist ideas, but these were absorbed by the predominantly English-speaking labour force. Thus, most of the strands of socialist thought and labour politics in the English-speaking world were represented in the white South African labour movement. ${ }^{16}$

In order to attract and retain the required skills, the white immigrants were paid high wages and accorded a privileged status. The privileges of (foreign) skilled labour were extended to incorporate unskilled and semiskilled white workers, such as indigenous Afrikaners. ${ }^{17}$ Because of the nature of deep-level mining and the low average mineral content of the ore, South Africa's minerals could only be produced profitably at low production costs by creating and containing a vast supply of cheap available labour, thus initiating the proletarianization of the country's black labour force. ${ }^{18}$ Because the white workers feared the numerical superiority and labour competition of black workers, they effectively excluded them from opportunities to acquire competitive skills, knowledge, and expertise ${ }^{19}$ by introducing labour legislation and other discriminatory practices on the basis of a colour-bar in the work place. ${ }^{20}$ Consequently, all white workers became an elitist "labour aristocracy", ${ }^{21}$ regardless of their skills, and correspondingly, black workers formed a pool of unskilled, cheap labour, ${ }^{22}$ because organized labour remained a

I 5. D. Ticktin, “The Origins of the South African Labour Party, I888-1910" (unpublished Ph.D. thesis, University of Cape Town, 1973), pp. 2-3, 5; R.K. Cope, Comrade Bill: The Life and Times of W.H. Andrews, Workers' Leader (Cape Town, I943), p. 43.

16. S. Johns, Raising the Red Flag: The International Socialist League and the Communist Party of South Africa 1914-1932 (Bellville, 1995), p. 25; A.A. Mawby, "The Political Behaviour of the British Population of the Transvaal, I902-1907” (M.A., University of the Witwatersrand, 1969), p. 213.

17. D. Ncube, The Influence of Apartheid and Capitalism on the Development of Black Trade Unions in South Africa (Johannesburg, 1985), pp. I I 23.

I 8. E. Webster, "Background to the Supply and Control of Labour in the Gold Mines", in idem (ed.), Essays in Southern African Labour History (Johannesburg, I978), pp. 9-1 9, 9, I8.

19. N.E. Wiehahn, "Industrial Relations in South Africa: A Changing Scene", in D.J. van Vuuren et al. (eds), Change in South Africa (Durban, I983), p. 168.

20. See G.V. Doxey, The Industrial Colour Bar in South Africa (London, 196r).

21. See Katz, A Trade Union Aristocracy, p. 77.

22. Ncube, The Influence of Apartheid, p. 24. 
domain exclusively controlled by the white working class until the early I 920 s. $^{23}$

The discovery of minerals in South Africa made trade unionism possible and even inevitable. ${ }^{24}$ Trade-union organization from the I 880 os onwards was the result of the efforts of skilled immigrant artisans who, if they did not belong to branches affiliated to parent bodies in Britain, established local trade unions modelled on British counterparts. ${ }^{25}$ The predominantly British character of the miners, the habits of the British workshop, and the tradition of the British trade unions became established on the Witwatersrand. ${ }^{26}$ Therefore the trade-union and political wings of the (white) South African labour movement were organized in the same way as were similar bodies and movements in Britain. ${ }^{27}$

Established in I 892, the short-lived Labour Union was one of the first prominent trade unions on the Witwatersrand which catered for white mineworkers generally. ${ }^{28}$ The primary institutions used for linking up various labour organizations were the trades and labour councils that were formed in various industrial centres in South Africa. The strongest and most influential council was the Witwatersrand Trades and Labour Council (WT\&LC). Formed in 1902, the WT\&LC was the driving force behind labour politics in postwar Transvaal. The WT\&LC became South Africa's foremost political and industrial organization until its political functions were taken over by the South African Labour Party (SALP) in I909. Workers of British origin took the initiative in the formation of the SALP, and the party was mainly supported by these workers. One of the SALP's most notable political features was its white-labour policy which strove to protect white labour from black encroachment. ${ }^{29}$

A variety of socialist organizations, clubs, and parties were established after the Anglo-Boer War such as the Clarion Fellowship (Durban, 1903), the Social Democratic Federation (Cape Town, 1904), the Independent Labour Party (Pretoria, I906), the Social Democratic Party (Durban, I 908), the Socialist Society (Johannesburg, I 909), and the Socialist Labour

23. See, for example, K. Luckhardt and B. Wall, Organise or Starve! The History of the South African Congress of Trade Unions (London, 1980).

24. W.H. Andrews, Class Struggles in South Africa (Cape Town, 1940), p. I 2.

25. Katz, A Trade Union Aristocracy, p. 447.

26. C.W. de Kiewiet, A History of South Africa: Social \& Economic (London, I957), pp. 2 I I$2 \mathrm{I} 2$.

27. E. Roux, Time Longer than Rope: A History of the Black Man's Struggle for Freedom in South Africa (London [etc.], I948), p. I30; M. Horrel, South African Trade Unionism: A Study of a Divided Working Class (Johannesburg, I96I), p. I.

28. Katz, A Trade Union Aristocracy, p. 22.

29. Ticktin, "The Origins of the South African Labour Party, I 888-I9I0", pp. 25, I I 7, 4I 4-44I; E. Gitsham and J.F. Trembath, A First Account of Labour Organisation in South Africa (Durban, 1926), p. I2; Cope, Comrade Bill, p. 66; E.S. Sachs, The Choice Before South Africa (London, I952), p. 47. 
Party (Johannesburg, I910). ${ }^{30}$ Thus the proletarian strata of the white labour movement of South Africa and the strikes with which they were involved consisted of low-skilled indigenous Afrikaners, immigrants from the European, and especially the English working class, as well as a sprinkling of English middle-class immigrants, who were attracted to South African labour and socialist politics. ${ }^{3 \mathrm{I}}$

The pioneering trade unions were craft unions that monopolized and controlled the supply of skilled labour through strict demarcation of trades, and restricted access to union membership by means of the apprentice system and the closed-shop principle. ${ }^{32}$ It was in their interests to keep admissions to the craft low and the criteria rigorous, to ensure a strong demand for their skills and correspondingly high wages. Thus, these craft unions were by nature elitist and racially exclusivist, concerned primarily to protect the position of the skilled (white) workers from competition by other less, or unskilled (mainly black), workers. ${ }^{33}$

A perusal of the contents of the locally produced socialist and laboursponsored newspapers reveals a white working class extraordinarily wellinformed and knowledgeable about labour matters and the trade-union affairs of the global industrial world. In his seminal study on the intellectual life of the British working classes, Jonathan Rose explains that British working-class literacy stems from an eighteenth-century autodidact culture that flourished especially in Scotland and stemmed from a desire for self-improvement. These classes were influenced by John Ruskin, William Morris, and Robert Blatchford's views on socialism, and by Thomas Carlyle's critique of the social order. A tradition of selfeducation and of setting up their own networks of working-class libraries was established, especially among Scottish miners and South Wales colliers. In the Welsh coalfields, for instance, many workers were wellversed in the Marxist classics. ${ }^{34}$

30. Ticktin, "The Origins of the South African Labour Party, i888-1910", chs 2, 5, 6, 8.

3. See Katz, A Trade Union Aristocracy, pp. I3-85, and W.P. Visser, "Exporting Trade Unionism and Labour Politics: The British Influence on the Early South African Labour Movement", paper presented at the British World Conference (University of Cape Town, 2002), pp. I-I7.

32. J. Lewis, Industrialisation and Trade Union Organisation in South Africa, 1924-55 (Cambridge, 1984), pp. 17-28. See also E.J. Hobsbawm, Labouring Men: Studies in the History of Labour (London, 1968), p. 290.

33. D. O'Meara, "White Trade Unionism, Political Power and Afrikaner Nationalism", in Webster, Essays in Southern African Labour History, pp. I64-180, I68.

34. J. Rose, The Intellectual Life of the British Working Classes (London, 200I), pp. I6ff. On a Scottish socialist immigrant in South Africa who was also influenced by Carlyle, see J. Hyslop, "A Scottish Socialist Reads Carlyle in Johannesburg Prison, June 1900: Reflections on the Literary Culture of the Imperial Working Class”, Journal of Southern African Studies, 29 (2003), pp. 639-655. On the self-education and self-improvement of the working class, see also E.J. Hobsbawm, The Age of Empire 1875-1914 (London, 1987), p. 263. 
Indeed, the wide circulation of British labour and socialist literature locally also contributed to the growth of the South African labour movement. Robert Blatchford's popular socialist weekly, The Clarion, which included large sections of literary criticism, and his other publications, such as the socialist fable, Merrie England, had a sizeable readership in South Africa. ${ }^{35}$ British labour papers, such as The Clarion, Forward, Labour Leader, and Lansbury's Herald, were circulated freely. Even copies of the Italian socialist paper, Avanti, found their way to this country, ${ }^{36}$ while a local socialist weekly also advertised subscriptions to The Socialist, the organ of the Socialist Labour Party in Glasgow, and to the International Socialist Review of the Charles H. Kerr Company based in Chicago. ${ }^{37}$ It is clear that South African trade unionists were greatly influenced by the propaganda and programmes of their counterparts overseas. ${ }^{38}$

Socialist and labour ideas and literature from abroad were disseminated in various ways in South Africa. There were prominent migrants with a radical left background such as Israel Israelstam, a spokesperson for the SLP. Tom Mann, the renowned British syndicalist orator, visited South Africa in I910, I9I4, and 1922. South African-based militants, such as Bill Andrews, the organizing secretary of the South African branch of the British Amalgamated Society of Engineers, Tom Glynn, a leading figure of the South African section of the revolutionary syndicalist Industrial Workers of the World (IWW), and Archie Crawford toured industrial centres overseas where they were exposed to new radical and extremist views regarding labour organization. Reprints of the IWW and other articles emanating from the international socialist press also appeared regularly in local leftist organs such as Voice of Labour and The International.

In addition, the International Socialist League (ISL) (founded in Johannesburg, I9I5) and the Industrial Socialist League (founded in Cape Town, I9I8) maintained their own libraries and socialist Sunday schools, where left-wing ideas were circulated. There were also socialist pamphlets, book sales, and mail orders. Left-wing organizations such as the IWW, SLP, and ISL held regular Sunday meetings in Johannesburg which provided key venues for literature sales. Social activities, such as the ISL's regular fundraising dances at West's Academy in Johannesburg, also

35. Ticktin, "The Origins of the South African Labour Party, I888-1910", p. Io. See also, for example, the critical discussions of Blatchford's views on war in the local socialist weekly, Voice of Labour, i I February i910, p. 66; ibid., i March I910, p. I 16; ibid., 6 May 1910, p. 208; and ibid., 3 May 19г 2, p. 5 .

36. Cope, Comrade Bill, pp. 98, 170.

37. See Voice of Labour, 9 June I9I I, p. I; and ibid., 24 November I9I I, p. 7.

38. Katz, A Trade Union Aristocracy, p. I3. 
provided opportunities for circulating socialist literature as well as leafleting working-class neighbourhoods, streets, shoppers, and Mayday paraders. 39

The links with the international world of labour, especially that of the British Empire, would have a profound influence on the racial attitudes of the white working class in South Africa. These attitudes reflected an ambiguity towards colour in the workplace. In a trenchant and pathbreaking essay, Jon Hyslop has revealed the fusion of class and racial consciousness that prevailed across the British Empire in the late nineteenth and early twentieth centuries. Hyslop argues that the white working class in the pre-World-War-I British Empire was bound together into an imperial working class by flows of population which traversed the world. The labour movements stemming from this imperial working class produced and disseminated a common ideology of white labourism. In this ideology, elements of the critique of exploitation and of racism were inextricably intermingled. This was an era of radical labour militancy, of profound ideological hostility to capitalism, and of the widespread influence of syndicalist doctrines in the unions.

This internationally constructed synthesis of militant labour and racist vision was a major cultural source of the beginnings of South African industrial segregation. The political concerns of white labour were disseminated around the empire by persons, newspapers, and by organizational links, such as trade-union branches affiliated to parent bodies. Their discourse centred on the idea that they were protecting the existing working class against the destruction of their wage and welfare gains. This was often supported by a kind of anticapitalist paternalism, in which labour leaders claimed to be protecting African and Asian workers against capitalist "enslavement" through inhibiting the use of cheap labour..$^{\circ}$

White labourism revealed a weird combination of racism and egalitarianism. Where white socialists took leadership positions in the white labour movement, they found themselves pushed towards an exclusive white labourist project. Some left-wing union leaders were able to reconcile themselves to this fate by way of the circuitous reasoning that, although African workers should have political rights in principle, in a situation in which Africans were living in an unfree condition, and could

39. See L. van der Walt, "Anarchism and Revolutionary Syndicalism in South Africa, I904I92 I" (unpublished Ph.D. thesis, University of the Witwatersrand); idem, "Bakunin's Heirs in South Africa: Race and Revolutionary Syndicalism from the IWW to the International Socialist League, 1910-21", Politikon, 31 (2004), pp. 67-89; Voice of Labour, 1908-1912; and The International, I915-1922.

40. J. Hyslop, “The Imperial Working Class Makes Itself 'White': White Labourism in Britain, Australia, and South Africa before the First World War", Journal of Historical Sociology, I 2 (1999), pp. 399-400, 402-403. 
thus be forced to perform cheap labour, the wage and welfare gains of white workers needed to be protected against "unfair" competition..$^{4}$

Regarding the relationship between strike papers and white labourism, in essence the latter was the dominant ideology of the South African strike press. The strike press defended the rights of the white working class against the capitalist class, which was perceived as the "enemy", that constantly endeavoured to undermine the interests of white workers by introducing cheap black workers into the labour market. Thus, it was Gandhi who declared in I914: "To the socialist of South Africa the brotherhood of man means brotherhood of the white man". ${ }^{42}$ These sentiments were typical of the ambiguities about colour that the white socialists of Johannesburg grappled with in the columns of their paper, Voice of Labour.

A weekly socialist newspaper, Voice of Labour was launched towards the end of September 1908 (originally as a "free sheet") to promote a broad General Workers' Union, and it ran until December I9I 2. It was edited by Archie Crawford (born in Glasgow, I883) and published by Mary Fitzgerald (born in Ireland c.I880s), his business partner whom he later married. According to its subtitle, the paper purported to be "a weekly journal of socialism, trade unionism and politics". Voice of Labour acted as a forum for socialists and labour supporters from across South Africa. From I910 it became the central point from which the doctrines of revolutionary syndicalism in South Africa emerged. Its subtitle was therefore also changed to "a weekly journal of socialism, industrial unionism and politics". 43

Although some socialists pleaded for a colour-blind policy towards workers of colour, ${ }^{44}$ others conveyed a thinly disguised racist attitude. A substantial number of Voice of Labour correspondents were of the opinion that workers of colour were intellectually not fit to be included into the ranks of socialist organizations, or even in a socialist state. To solve the "colour problem", segregation was "to be carried out at any cost", to prevent competition between black and white workers and the

4I. Ibid., pp. 406, 409. See also Katz, A Trade Union Aristocracy, pp. 448-449.

42. E. Gandhi, Gandhiji's Encounter with the Fourth Estate: A Story of Mahatma Gandhi and the Media (Durban, 2003), p. 29. See also Hobsbawm, The Age of Empire, p. 72.

43. Voice of Labour, 26 September 1908; H.J. and R.E. Simons, Class and Colour in South Africa I850-1950 (Harmondsworth, I969), pp. I4I, I52; L. van der Walt, “'A Class-Conscious Revolutionary Organisation Embracing all Workers Regardless of Craft, Race or Colour': The IWW and the Origins of Revolutionary Syndicalism in South Africa, 1908-1912", paper presented at the South African Sociological Association Congress (Saldanha Bay, 1999), pp. 4-9, I 5-I6, 24. Although Voice of Labour published inconsistent circulation figures, ranging between 2,000 and 5,000, Katz, A Trade Union Aristocracy, p. 313, states that its weekly circulation was small and did not exceed 500 copies.

44. Voice of Labour, I I December 1909, p. I. 
exploitation of both by capitalism. ${ }^{45}$ Even Crawford, the editor, stated that, although in principle he favoured the extension of the franchise to people of colour, and the admission of such persons to the ranks of socialism, this should be limited to individuals on the basis of merit. In carefully worded editorial statements, he also suggested his aversion to social equality with blacks and to the "idea of fusion" of races. ${ }^{46}$ In response to a remark by Tom Mann, who in I9I0 expressed the view that all workers - regardless of colour - should be organized, Voice of Labour reacted by stating that it was not concerned whether or not attempts were made to organize workers of colour, because such organization could be done better from within the ranks of coloured workers themselves. ${ }^{47}$

Regarding the use of the strike weapon to further their interests, Hyslop argues that both the Australian and South African labour movements took a position implying that they were not treated as sufficiently "white" by the upper classes, and fought to obtain this racial status for themselves. $4^{8}$ For instance, Voice of Labour reported on local strikes and incipient industrial revolt by workers resulting from reduced wages, increased working hours, and tyrannical or unhealthy conditions of labour. ${ }^{49}$ According to Jeremy Krikler, intense class-consciousness and anticapitalism were integral to the white workers' conception of themselves and their place in the world. ${ }^{50}$ Thus, Tom Glynn, who was also involved in the unsuccessful Johannesburg tramway strike of I9I I, ${ }^{\text {II }}$ was of the opinion that the rank and file of the workers on the Witwatersrand were "more ready for a general strike [...] than at any previous time in [their] history". Expounding the IWW's doctrine of revolutionary industrial unionism, Glynn argued that the strike weapon,

45. See ibid., 3 I July 1909, p. 4; ibid., 21 August 1909, p. 7; ibid., I3 November 1909, p. 9; ibid., 4 December 1909, pp. 6-8; ibid., I 8 December 1909, p. 9; ibid., 28 January 1910, p. 47; ibid., 22 April ı910, pp. 190-ı1; ibid., го May г9г 2, p. 4.

46. Ibid., 3 I July 1909, p. 9; ibid., I4 August 1909, p. 9; ibid., 2 I August 1909, p. 9; ibid., 4 December 1909, pp. 6-7; ibid., Iо May I9I 2, p. 4. See also Katz, A Trade Union Aristocracy, pp. $272-273$.

47. Voice of Labour, i 8 March I910, p. I 23. See also the paper's criticism of Mann's views on the colour question in South Africa in the issue of 25 March I9I0, p. I39.

48. Hyslop, "The Imperial Working Class", p. 402.

49. See Voice of Labour, 28 January 1909, p. 44; ibid., I4 January I910, pp. 17, 20; ibid., 2 February I910, p. 67; ibid., 20 January I9I I, p. 591; ibid., 24 March I9I I, p. 662; ibid., I 9 May I9I I, pp. 2, 3, 5; and ibid., 7 July i9i I, p. 4.

50. J. Krikler, "White Working-Class Identity and the Rand Revolt", paper presented at the History Workshop \& Wits Institute for Social and Economic Research, University of the Witwatersrand (Johannesburg, 200I), p. I 5 .

5. Van der Walt, "A Class-conscious Revolutionary Organisation”, pp. 19-20, 24, 35-38; Walker and Weinbren, 2000 Casualties, pp. 28-30. By I9I I and I9I 2, Voice of Labour served as the official organ of the IWW, advocating "industrial unionism and revolutionary socialism". See Voice of Labour, 30 June I9I I, p. 7; and ibid., I6 February 191 2, p. 3. 
when properly utilized, was the most powerful, if not the only, weapon at the workers' disposal. ${ }^{2}$

In its editorials, Voice of Labour also captured the festering militant mood of the international working-class movement before the World War I: "Never in the whole history of the working class movement have there been such stirrings of industrial unrest as in the last few years [...] today [I9I I] one can safely claim that no 'civilised' country has failed to exhibit the proletariat in revolt". 53

A last but very important factor conducive to the emergence of a prostrike press ${ }^{54}$ was the extensive presence of printers in the nascent South African printing industry, many of whom had clearance cards from the London Society of Compositors (LSC). 55 By I88I-I882 there was already a union for printers in Cape Town. Eventually a united printers' union that was organized on a national basis, the South African Typographical Union (SATU), was founded in Johannesburg in 1898. Its constitution was originally largely based on the LSC. ${ }^{6}$ In I905, the South African Typographical Journal claimed that, next to mining, printing "afforded employment to the largest number of white men" in the Transvaal. 57 According to Katz, the presence of so many printers in the Transvaal can be accounted for by the stability and high circulation figures of a number of daily newspapers, an increase in the numbers of weekly and monthly periodicals, and the presence in Pretoria of the Government Printing Works. ${ }^{8}$ Consequently, South Africa began to produce its own skilled and experienced master printers, compositors,

52. Voice of Labour, 21 April i91 I, p. 8. Van der Walt, "A Class-Conscious Revolutionary Organisation”, pp. I 4, 20-2 I, 26, however, emphasizes that the IWW was open to all workers the first labour union in South African history to be so, as every other union of that period had a colour bar. Whereas the local right-wing conservative and reformist craft unionists and adherents of the SALP were influenced by, and shared a common ideology of, white labourism with their British and Australian trade-union and Labour Party counterparts, the revolutionary syndicalism of the South African section of the IWW had its ideological roots in the United States.

53. Voice of Labour, I I August I9I I, p. 4. See also ibid., 7 July I9I I, pp. 4-5.

54. For an excellent exposition of the importance of printers as agents of political change and initiators of a pro-strike press in the case of early twentieth-century Russia, cf. Ruud, "The Printing Press as an Agent of Political Change”, p. 383 . According to Ruud, many printers in Russia recognized the power of the printed word to persuade and inform, and came to realize that they themselves could wield power by printing their own writings.

55. A.J Downes, Printers' Saga: Being a History of the South African Typographical Union (Johannesburg, I952), pp. ix, I, 4 .

56. Ibid., pp. I-46; E. Gitsham and J.F. Trembath, A First Account, p. I s; Katz, A Trade Union Aristocracy, pp. 2I, 245 .

57. Quoted by Katz, A Trade Union Aristocracy, p. 3. The Transvaal was an ex-Boer republic in South Africa, with Johannesburg and the Witwatersrand as its industrial core.

58. Ibid., p. 4 . 
and typesetters, many of whom found employment with labour newspapers and trade-union journals. 59

As far as the relationship between the strike press and the established workers' press is concerned, the former came into being under abnormal labour circumstances. Strike papers were initiated as a result of the outbreak of strikes, and were produced by workers, such as SATU members, who had prior editorial experience and who possessed certain printing skills. As such, the strike papers were not mere extensions of the established labour press, although the latter - in principle and for the sake of worker solidarity - usually also adhered to the strike cause. Therefore a subtle distinction is made between pro-strike labour papers and actual strike publications.

As one of the most influential and numerically strongest unions on the Witwatersrand, SATU maintained an ambiguous policy towards coloured labour. Coloureds were admitted into SATU provided they served their apprenticeship, claimed the same wages as white men, and observed the rules of the union. In this way, the union safeguarded equal wages for all skilled printers - white and coloured. Yet membership of SATU did not include Africans, and the union disapproved of skilled African printers competing directly with whites. SATU's hostility and racial prejudice towards Africans was not only because the latter undercut white printers' wages, but also because they were regarded as uncivilized people who could not attain white standards. Similarly, Asians were refused admission on the premise that they would be unable to attain white standards of living. And in practice even coloureds were not welcomed as fellow workers by Transvaal members of SATU. ${ }^{60}$

\section{THE STRIKE PRESS AND THE I 9 I 3 WITWATERSRAND MINERS'STRIKE}

The production of early twentieth-century strike papers from I 9 I 3 to I 922 - a period of intense and violent industrial unrest - was preceded by the appearance of the Cape Town Herald, Strike Edition, during a Cape Town printers' strike in 191 г. ${ }^{61}$ Setting the tone for militant strike action that commenced with the miners' strike of I9I3, the paper stated that it was

59. Internationally, there seemed to be good reasons why printers were among the first workers to organize. Their skills and access to the means for mass-producing ideas and information made them especially useful in furthering workers' causes. See Ruud, "The Printing Press as an Agent of Political Change", pp. 383-384.

60. Katz, A Trade Union Aristocracy, pp. 26, 23 Iff.

61. Downes, Printers' Saga, pp. 208, 221-222, 227-228, 327; Gitsham and Trembath, A First Account, pp. 31-32; Walker and Weinbren, 2000 Casualties, p. 3 I. 
founded "to fight the battles of the workers of South Africa, and to act as an antidote to the capitalist poison". ${ }^{62}$

The vulnerable position of skilled and semiskilled white labour vis-à-vis unskilled black labour is vividly illustrated by this period, which was characterized by a bloody trial of strength between capital and the state, on the one hand, and labour, on the other. Frederick Johnstone explains that the proletarianization of white workers led to their structural insecurity, which was greatly aggravated by exploitable, cheap, black labour. For the skilled white workers this posed the threat of displacement from employment, while for the unskilled white workers it meant the restriction of employment opportunities. Especially the white mineworkers were thus constantly faced with the potential threat of undercutting and displacement by mining capital in favour of cheap black labour, and this would lead to their taking drastic measures, such as the use of the strike weapon, to protect themselves against the threat. ${ }^{63}$

By the end of I9I2, the general mood of unrest which permeated all groups of white workers in the mining industry was indicative of future trouble. The contributory causes of the miners' strike were the high cost of living on the Witwatersrand; the demand for the establishment of a minimum or subsistence wage for whites; white miners' fears of being replaced by cheap black labour and their insecurity of tenure; the demand for overtime payment and for nightwork in trades or industries; the demand for an eight-hour working day for all underground mineworkers, because of their susceptibility to miners' phthisis; the unhealthy mining conditions that created occupational miners' phthisis; and the refusal of the Chamber of Mines to recognize trade unions. These circumstances engendered a climate of hostility and militancy among white workers. ${ }^{64}$

The immediate cause of the strike was the dismissal of five underground mechanics on the New Kleinfontein goldmine near Benoni, who refused to comply with altered hours of work after they had lost their Saturday halfholiday. Eventually a strike was declared on 26 May i9i 3. The Transvaal Federation of Trade Unions, a co-ordinating body of Witwatersrand trade unions which came into existence formally in I9I I, took command of the New Kleinfontein dispute. A strike committee consisting of delegates from the various trade unions was appointed under the auspices of the Federation. ${ }^{65}$ The Kleinfontein management refused to negotiate with the strike committee and took on "scabs" (strikebreakers) to do the job. However, the strike escalated and became more violent. By the beginning

62. Cape Town Herald, (strike edition), i6 June i9i I, pp. I-2, 5.

63. F.A. Johnstone, Class, Race and Gold: A Study of Class Relations and Racial Discrimination in South Africa (Lanham, MD, I976), pp. 57-59, 64-82, I45-150.

64. Katz, A Trade Union Aristocracy, pp. $322 \mathrm{ff}$.

65. Ibid., pp. 257-262, 385, 387, 4I3-4I4; Downes, Printers' Saga, p. 300. 
of July I9I 3, I9,000 white workers from the gold mines and power stations were on strike.

At the climax of the strike, on 4 and 5 July I9I 3 , a mob set fire to the goods shed at the Johannesburg station and burnt down the premises of The Star (the mouthpiece of the Chamber of Mines). As the Union Defence Force had not as yet been properly constituted to quell the unrest, the government was compelled to negotiate with a deputation of the strike leaders. Altogether twenty-five people, including innocent bystanders, were killed during the unrest. It was agreed that all the strikers would be reinstated and that a judicial committee would be appointed to investigate the workers' grievances. The strikebreakers were to be dismissed, but were to be paid a year's salary at government expense. The forces of labour had apparently gained a victory. ${ }^{66}$

The pro-labour press was heavily engaged in the miners' strike of I9I3. As the strike progressed towards its climax, even the tone of the otherwise sedate editorials and articles of The Worker became increasingly militant and left-wing oriented. This reformist weekly labour newspaper ${ }^{67}$ had been launched towards the end of January I 909 under the auspices of the Johannesburg branch of SATU. From I9I 2 until its demise in October I9I4, as a result of economic decline during the First World War, The Worker became the official organ of the segregationist SALP. ${ }^{68}$ Its editor was Wilfred Wybergh who, as a close friend of F.H.P. Creswell, the SALP parliamentary leader, staunchly supported the party's white-labour policies in his editorials. ${ }^{69}$

Although The Worker regarded acts of violence against scabs as regrettable, the paper blamed this on "the futile policy of irritation" which the mine bosses adopted towards the strikers. By June I9I 3 , the early days of the strike, The Worker still admonished the strikers to consider their

66. UG, 55-1913, pp. i-lxvi; UG, 56-1913, pp. I-28; O’Quighley, “The 1913 and I914 White Workers' Strikes”, pp. I-26; Walker and Weinbren, 2000 Casualties, pp. 34-36; Katz, A Trade Union Aristocracy, pp. 396-429.

67. According to Van der Walt, "A Class-Conscious Revolutionary Organisation”, p. 9, labour reformism envisages a situation in which the unions sponsor a Labour Party that can get access to the state, which is regarded as the real instrument of socialist change. See also The Worker, I 8 September 1913, p. 3; ibid., 23 October 1913, p. 2.

68. Ticktin, "The Origins of the South African Labour Party", p. 554; Downes, Printers' Saga, pp. 254-255; E.N. Katz, "White Workers' Grievances and the Industrial Colour Bar, 1902I913", The South African Journal of Economics, 42 (1974), p. I27; Johannesburg Public Library [hereafter, JPL], SALP Collection, Minute Book 3, Report of "The Worker" Committee to the Annual Conference at East London, 28 December i914, p. KJ 20.

69. Cope, Comrade Bill, p. I62; Katz, A Trade Union Aristocracy, pp. I 20, I42; D. Ticktin, "The War Issue and the Collapse of the South African Labour Party, I9I4-I5", South African Historical Journal, I (1969), p. 62. Although The Worker's circulation figures could not be ascertained, evidence in Ticktin, "The Origins of the South African Labour Party", p. 554 suggests a figure of approximately 2,000 . 
options carefully. Should a general strike be called, the strikers should use it as a "moral appeal to public opinion" to further their cause, rather than as an instrument of violence. The latter option would unleash counterviolence from the authorities towards them. ${ }^{70}$ However, by July I 9I 3 , the paper used war as a metaphor to describe the struggle between government and capital, on the one hand, and labour, on the other. It encouraged the white workers to fight "not to a finish [...] but to [a moral] victory". For The Worker, such victory meant bringing parliament "to its knees" to "extort substantial legislation in the workers' interest" $7^{11}$

Archie Crawford and Mary Fitzgerald, who became disillusioned with left-wing politics after the demise of Voice of Labour in I9I 2, abandoned their revolutionary socialist positions entirely..$^{72}$ They rejoined the ranks of the mainstream white labour movement and played active roles in the I9I 3 strike in inciting the strikers and intimidating scabs. ${ }^{73}$ Indeed, as the strike committee were of the opinion that the establishment press published too many misleading reports on the strike, they started a militant bi-weekly, The Strike Herald, edited by Crawford. This broadsheet, which appeared on Wednesdays and Saturdays, was the official organ of the Federation of Trades and published by the Kleinfontein Strike Committee in Benoni. It sold at $3 \mathrm{~d}$ per copy and also carried commercial advertisements. The first issue of The Strike Herald appeared on Saturday 2 I June I9I 3. The paper was printed by Modern Press, co-owned by Mary Fitzgerald. It was the same printing press in Fox Street, Johannesburg, which used to print Voice of Labour. ${ }^{74}$

Elaine Katz states that the daily speeches by strike leaders and the articles that were published in The Strike Herald had the effect of arousing the strikers to a fever pitch. They were imbued with the idea of solidarity and adopted the slogan advocated by the paper that "an injury to one is an injury to all".75 Frances Hunter claims that Crawford and Fitzgerald "worked shifts twenty-four hours a day to bring out Voice of Labour news-sheets every few hours in the days that followed"..$^{76}$ Apparently the demand for the first edition of The Strike Herald was so great that a second

70. The Worker, 26 June I913, p. 4.

71. Ibid., 3 July i91 3, p. r. Unfortunately, only an incomplete set of this newspaper, dating from June I9I 3 to October I9I4, was preserved.

72. Van der Walt, "A Class-Conscious Revolutionary Organisation”, pp. 38-48.

73. O'Quighley, “The I9I3 and I9I4 White Workers' Strikes”, pp. 6, i8, i9; Katz, A Trade Union Aristocracy, pp. 398, 428; Walker and Weinbren, 2000 Casualties, p. 33.

74. The Strike Herald, 2 I June I9I3, pp. I, 4; ibid., 25 June I9I 3, p. 7; ibid., 26 July I9I 3, p. 8; ibid., 2 August 1913, p. 4; Katz, A Trade Union Aristocracy, p. 399; F. Hunter, "Who Was Pickhandle Mary?" (Johannesburg, n.d.), p. 19. No circulation figures for this paper could be ascertained.

75. Katz, A Trade Union Aristocracy, pp. 403-404; The Strike Herald, 21 June I9I 3.

76. Hunter, "Who Was Pickhandle Mary?", p. 29. Hunter is clearly mistaking Voice of Labour, that had already ceased to exist by the time of the I9I 3 strike, for The Strike Herald. 


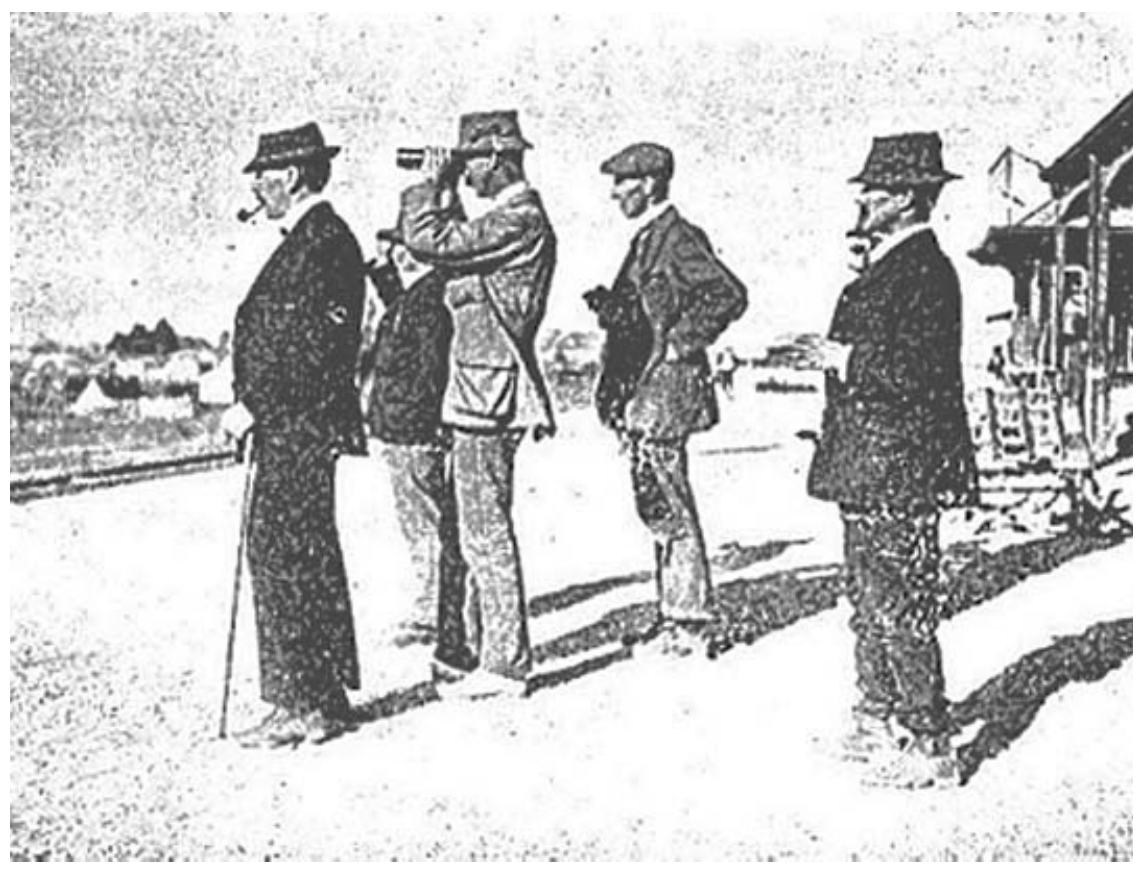

Figure I. "The Benoni Railway Station commands an uninterrupted view of the northern roads leading from Johannesburg to the strike area, and here a picket is constantly placed, which - as shown in above photo - brings powerful glasses to bear upon conveyances passing eastwards on these roads. If a load of 'scabs' is discerned, the signal is passed along the main body of strikers, who hastily prepare to receive their distinguished visitors."

A photo from The Strike Herald showing a picket on the lookout for scabs during the 1913 miners' strike.

impression had to be printed. In the second issue, the editor declared: "The Herald is a herald of Revolt". ${ }^{77}$ Still, the paper struggled to survive. The Strike Herald appeared only four times until the issue of 26 July i9i 3 . In that period, Crawford, the editor, was arrested twice on a charge of inciting public violence and the greater part of one edition was seized by the authorities. Crawford was not sure whether the paper would be allowed to continue without government interference, but he nevertheless expressed the hope that the Herald could be produced at least once weekly until the strike period passed..$^{8}$ Indeed, it would appear as if the police, at that stage, contemplated halting publication of this broadsheet. ${ }^{79}$

77. The Strike Herald, 25 June I913, pp. 8, 9.

78. Ibid., 26 July 1913, pp. 2, 4. See also ibid., 28 June 1913, p. 6; ibid., 2 August 1913, p. 4; Central Archives Depot, Pretoria [hereafter, CAD], SAP vol. 8, file no. 6/147/I 3 , press cuttings re I9I 3 strike: The Pretoria News, I3 September I9I3.

79. CAD, JUS vol. I65, file no. 3/54I/1 3, general file re Witwatersrand Strike: J. de V. Roos to Minister of Justice, 25 June 1913. 
An outstanding feature of The Strike Herald's contents was its reflection of the intense hatred that the strikers bore towards scabs. According to Mary Fitzgerald, intimidating and assaulting scabs was a popular "sport" amongst strikers, and such actions were encouraged and condoned by the Herald. The paper was actually utilized as an instrument of intimidation against scabs. Their characters were besmirched, and photos picturing strikers with pickhandles and binoculars searching for scabs were published. To assist the "scab hunters" in their "scab hunting", the Herald published a scab list with a black border and quoted from Genesis I. 25 : "And God made [...] everything that creepeth upon the earth after its kind" ${ }^{80}$ However, the establishment press, which abused the strikers and revealed a lack of insight into the claims of mineworkers, played an equally significant role in intensifying unrest among the white working class. For example, an article in the Pretoria News stated that "people who hoist the red flag must be prepared for the machine gun". This statement was forcefully condemned by the editor of The Strike Herald. ${ }^{8 \mathrm{I}}$

In general, The Strike Herald's columns traced the course of the strike and events as they unfolded during the strike as well as printing speeches and articles by strike and SALP leaders, such as Mary Fitzgerald, George Kendall, J.T. Bain, D. McKerrell, F.H.P. Creswell, J.J. Ware, and Thomas Boydell. There were also reports of victimization of strikers and strike leaders by employers and the authorities. The Star was criticized for its alleged encouragement of the authorities to end the strike by force. Cartoons depicting Big Capital's manipulation of capitalist editors and their newspapers, and the Chamber of Mines and capitalists exploiting mineworkers, were printed. In addition, the paper published the words of The Red Flag, the workers' song, as well as photos of strike leaders and strike events. The Herald even printed cable news of British press comments on the strike events, and the debate in the House of Commons on the use of imperial troops to suppress the strike. ${ }^{82}$ The paper welcomed the "class-conscious and whole-hearted solidarity" of the Afrikaner workers with the strike, which was "sufficient to cheer the heart of a Debs or a Tom Mann". ${ }^{83}$ The Herald even carefully put the case for organizing African miners to improve their wages and conditions as well. ${ }^{84}$

80. UG, 55-1913, pp. xx-xxii; UG, 56-1913, p. 8; Cd., 7348-1914, pp. 170, 213; Katz, A Trade Union Aristocracy, pp. 40 I-404; The Strike Herald, 2 I August 1913, p. 8; ibid., 25 June I9I3, pp. 5, 9-I0, I4-I 5; ibid., 28 June I9I3, pp. 5, 8-9, I3-I 5; ibid., 2 July I9I 3, p. 2; ibid., 2 August I9I3, p. 4 .

8I. Katz, A Trade Union Aristocracy, p. 425; The Strike Herald, 25 June I9I 3.

82. See The Strike Herald issues from 2 I June to 2 August I9I3.

83. The Strike Herald, 28 June i91 3, p. 9. See also ibid., 26 July i9i3, p. I. Tom Mann was an influential personality of the British syndicalist movement, and Eugene V. Debs, a renowned leader of the American socialist movement.

84. The Strike Herald, 28 June 1913, p. I0. See also ibid., 25 June 1913, p. 10; and Simons and Simons, Class and Colour, p. I59. 


\section{The Chamber of Mines and the Mine Worker}

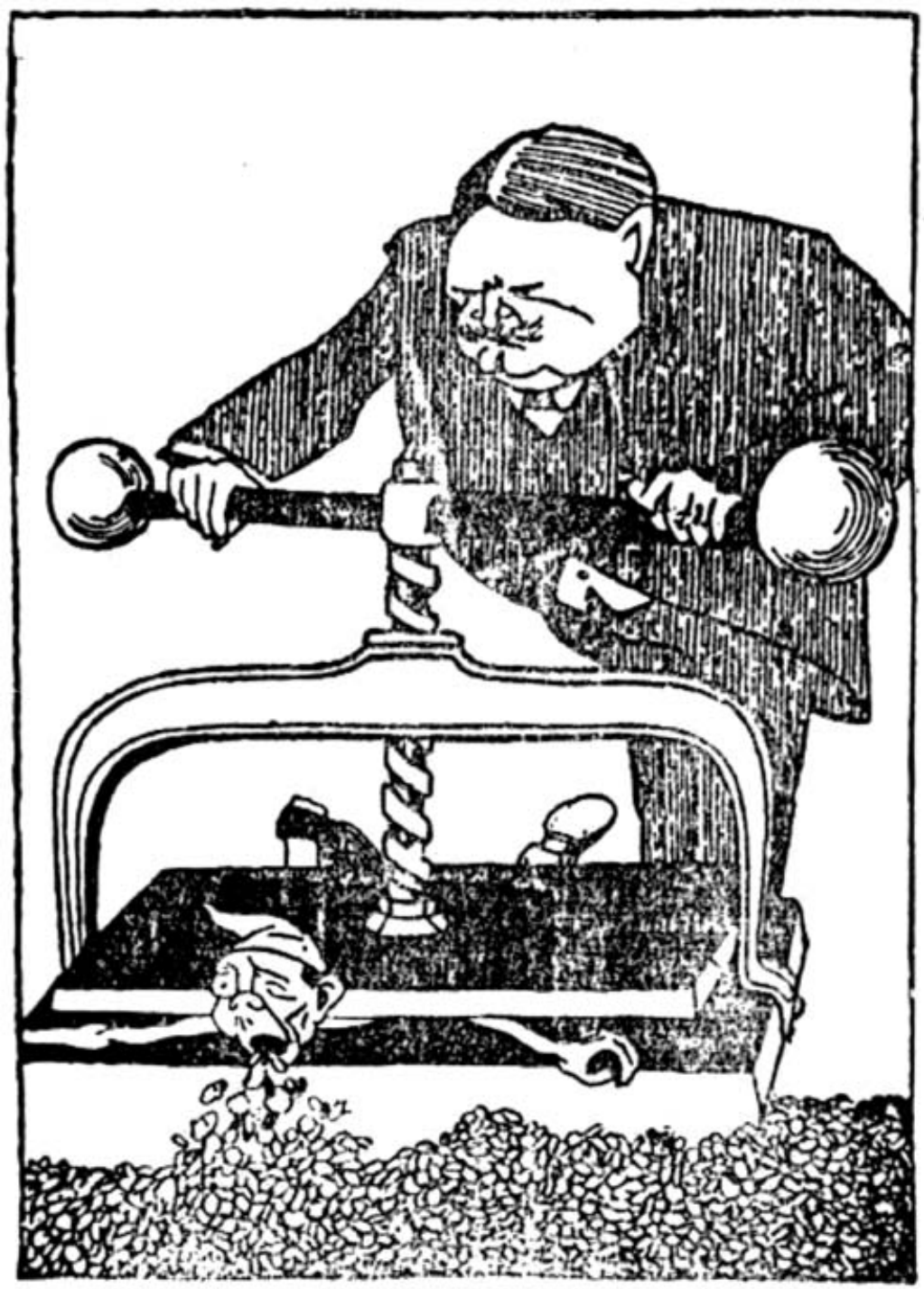

Figure 2. A cartoon from The Strike Herald of I9I3. 
Although on 3I July I9I3 the header declared that The Strike Herald was to be issued daily, ${ }^{85}$ the Federation accepted the settlement reached between the government and the strike committee the very same evening and called the strike off. As a result, the Herald appeared for the last time after seven issues on 2 August 19I3. Crawford was very disgruntled at the Federation's decision and declared that "we would almost call it 'defeat". The forms that had already been prepared for the Herald's second daily edition on I August were therefore broken up and preparations made to bring out the final issue. Under these circumstances the losses were considerable. Crawford thought that, should the Herald have continued, "a paying daily working-class paper could have been established". ${ }^{86}$

As a result of the widespread violence on 4 and 5 July I9I3 the government suspended all newspapers on the Witwatersrand for three days. ${ }^{87}$ Therefore, the Johannesburg SATU branch decided that the managers of the newspapers be asked for permission to print a newssheet under the auspices of the typo union "giving the bold facts of the appalling events of the past few days, such to be published with a mourning border". A sheet called The News was thus published and distributed with the consent and cooperation of the management of the Rand Daily Mail, The Transvaal Leader, and The Evening Chronicle. It was the only newspaper on the Witwatersrand that was to appear on Monday 7 July I9I 3 , the day of the funeral of the victims who were shot during the violence.

According to John Shorten, the consent and cooperation of the Mail and the Leader were influenced by the fact that their printing plants were protected by SATU members during the violence of 4 and 5 July. The Chronicle placed its plant at the disposal of the printing committee and their staff volunteered to produce the job. The Central News Agency distributed the sheet without charge. The Evening Chronicle claimed that 40,000 copies of The News were sold immediately. The sheet was sold at $3 \mathrm{~d}$ per copy and all profits accrued, amounting to $£_{2} 86$ 6s 8d, were handed over to a fund for the relief of the dependants of the deceased victims. ${ }^{88}$ The headline of The News proclaimed that it had been issued by SATU at the request and by the authority of the Transvaal Federation of Trades. ${ }^{89}$ The News consisted of a list of those killed and injured; a copy of two proclamations, calling upon all citizens to maintain public order and

85. The Strike Herald, 3 I July I91 3, pp. I, 2.

86. Ibid., 2 August 1913, p. 4.

87. Cd., 694I-1913, p. 9.

88. Downes, Printers' Saga, pp. 361-362; Walker and Weinbren, 2000 Casualties, pp. 35, 39; Katz, A Trade Union Aristocracy, p. 4I 4; The Nerws, 7 July 19I 3; The Evening Chronicle, I 2 July I9I3, p. I I; J.R. Shorten, The Johannesburg Saga (Johannesburg, I970), p. 262.

89. The Nerws, 7 July I9I3. 
refrain from attending gatherings, etc., and prohibiting the sale of arms and ammunition; and the funeral arrangements for the victims. $9^{\circ}$

Under conditions similar to the situation that led to the publication of The News in Johannesburg, a single issue of another broadsheet, the Strike Special, appeared on Sunday 6 July I9I 3 in Pretoria and was sold at $3 \mathrm{~d}$ per copy. The Strike Special was produced by the proprietors of The Transvaal Chronicle, sister paper of The Evening Chronicle, in response to numerous requests, and in view of the closing down of the Johannesburg newspapers and the anticipated stoppage of the Sunday papers. The sheet also stated that the sum of $3 \mathrm{~d}$ was charged, not because the proprietors had contemplated making any profit, but in order to meet the extra expense of producing a newspaper "under hurried conditions on a Saturday evening". The Strike Special, which was published under the SATU label, also contained information on the terms of settlement and ample descriptions of the violence, destruction, plundering, and bloodshed in the streets of Johannesburg and Benoni on 5 July I9I3. Mention was made of a one-day strike by Pretoria railway and cement factory workers in solidarity with the events on the Rand, and of military actions in and around Pretoria..$^{9 \mathrm{I}}$

The terms of settlement of the I9I 3 strike reached by the Federation and the government were not readily accepted by all strikers. ${ }^{2}$ The Worker was very critical of the government's handling of the whole affair. It cautioned the workers against allowing the euphoria of winning the strike to get the better of them. They were to guard against nullifying the concessions made by the government and the mining industry through the inexperience of their negotiators. ${ }^{93}$

\section{STRIKE PUBLICATIONS AND THE I 9 I 4 GENERAL STRIKE}

Industrial relations remained tense for the rest of I9I3. Emboldened by success and carried away by the new enthusiasm for trade unionism, many trade unions and their leaders became increasingly militant. ${ }^{94}$ In addition to other reasons, the I9I4 general strike arose from the state's perceived failure to honour some of the commitments made in the aftermath of the I9I 3 strike. According to C.W. de Kiewiet, the general strike of I9I 4 was a continuation and extension of the I9I 3 strike and was aimed at protecting the interests of white labour. ${ }^{95}$

90. Downes, Printers' Saga, pp. 362-363; Walker and Weinbren, 2000 Casualties, pp. 39-4I; The News, 7 July i9r 3.

91. Strike Special, 6 July I9I 3.

92. O'Quighley, "The I9I 3 and I9I4 White Workers' Strikes", pp. I6-I7.

93. The Worker, Iо July I9I3, p. 4. See also ibid., I I September I9I3, p. 4.

94. Katz, A Trade Union Aristocracy, p. 466.

95. De Kiewiet, A History of South Africa, p. I68. 
Railwaymen had not come out on strike as a body in I9I3. Yet their dissatisfaction increased when the Minister of Railways and Harbours, Henry Burton, and the general manager, William Hoy, made it evident by the end of that year that retrenchment of railway workshop employees had become an economic necessity. The Worker then declared that it was quite evident that the government was spoiling for a fight. ${ }^{96}$ In reaction to these developments a strike began on 8 January I9I4; the Federation of Trade Unions took control on I 3 January, and declared a general strike the next day. Railway employees from workshops in Pretoria, Johannesburg, Bloemfontein, Durban, and Cape Town, as well as coalminers in Natal, goldminers, and the typo union went on strike. This time, however, the government anticipated industrial action and was fully prepared to deal with the situation. Thousands of troops were mobilized, and on I 4 January I9I4 martial law was proclaimed in certain magisterial districts of the Transvaal, the Free State, and Natal.

All the strike leaders of the Federation were arrested as were hundreds of other strikers. This was followed by the temporary arrest of prominent SALP members, such as F.H.P. Creswell, W.H. Andrews, T. Boydell, and $\mathrm{M}$. Kentridge for contravening martial law regulations. By I 8 January I9I 4 the strike had been crushed with the loss of two lives. General Smuts, the Minister of Defence, believed, although this was never proved, that certain foreign strike leaders were dangerous men who had revolutionary syndicalist ideas of fomenting revolution and of overthrowing the state through industrial action. He consequently had nine of these men deported to Britain. ${ }^{97}$

Under martial law, the press was strictly censored. Cables which had been sent from England, for the information of the South African public, on protest meetings in the United Kingdom condemning the South African government's actions, were suppressed. The controlling officers were responsible for censoring all communications and newspapers. In this way any possible focus for the organization of strikers or mobilization of support was made ineffective or at least extremely difficult..$^{8}$

In January I9I4, a few days before a general strike was officially declared, the SATU executive voted in favour of participating in strike action upon the request of the Federation. In reaction to a proposal from the Federation's strike committee, the SATU executive resolved that a

96. See The Worker, 7 August I91 3, p. 5; ibid., 8 January I9I4, p. I; Cope, Comrade Bill, p. I 50. 97. Cd., 7348-1914, pp. 46-202; O’Quighley, “The I9I3 and I9I4 White Workers' Strikes”, pp. 34-50; Gitsham and Trembath, A First Account, pp. 4I-42. By the start of I9I4 Crawford was the Federation's secretary.

98. O’Quighley, “The I9I 3 and I9I4 White Workers' Strikes”, pp. 40, 45-46. See also Cd., 7348-1914, p. I06; and JPL, SALP Collection, Executive Report to the Annual Conference at East London, 28 December I9I4, p. KJ 20. 
daily news sheet would be printed on behalf of the strikers. ${ }^{99}$ The Worker verified this decision a week after the Federation's declaration of a general strike. ${ }^{100}$ However, the resolution was never put into practice, as even The Worker was forced to close under martial law regulations for a period of two months as from is January I9I4. ${ }^{\text {IOI }}$ In its last edition before closure under martial law regulations, The Worker published an appeal by the SALP to all South Africans to condemn the government's action against the strikers. The paper also cautioned the strikers to refrain from using violence, and from jeering and booing the police. ${ }^{\mathrm{IO}}$

According to A. O'Quighley, the strict censorship of the press at the time hampers proper assessment of the number of workers who struck. Just as the capitalist press distorted information in its own interest, so did the trade-union press in an attempt to rally support and prevent demoralization. ${ }^{103}$ For instance, The War on War Gazette, an antiwar socialist sheet that advocated pacifism at the start of World War I, alleged that the East Rand edition of The Star, the organ of the Chamber of Mines, proclaimed that the strikers on the West Rand had gone back to work, while the West Rand edition said the same about the strikers on the East Rand. ${ }^{104}$

As in the case of the I9I 3 strike, the strikers in the general strike of I9I4 also published their own strike bulletin in Johannesburg. In January I9I 4 a "special 'Strike' daily edition" of The Weekly Gazette, a one-penny worker's sheet edited by Fred Horak, who was also a member of the SALP, was published. The paper, which was explicitly prolabour and anticapitalist, claimed to give "all the latest, and accurate news from a

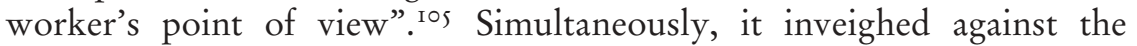
"yellow capitalist press which led the workers into capitalist traps" and "degradation". ${ }^{\text {106 }}$ The Weekly Gazette strongly identified with the cause of the railway employees during the strike and kept the strikers abreast of the latest developments in the various strike centres. The government's

99. Downes, Printers' Saga, p. 366.

I00. The Worker, is January i914, p. 4.

ıог. JPL, SALP Collection, Report of "The Worker" Committee to the Annual Conference at East London, 28 December I9I4, p. KJ 20. See also, The Worker, is January i9i4, p. 4.

I02. The Worker, is January I9I4, pp. I, 4-5.

I03. O'Quighley, “The I9I3 and I9I4 White Workers' Strikes”, p. 46. No source on the I9I4 strike provides clear-cut evidence as to the actual number of strikers involved in the dispute. Rosemary Mulholland, "White Labour and Politics: Railway Workers on the Witwatersrand I910-1924" (M.A., University of the Witwatersrand, 1988), ch. 5, suggests a figure of 6,000.

104. The War on War Gazette, io October 19I4, p. I. See also, The Worker, Is January I9I4, p. 4. In the light of O'Quighley's observations, the Gazette's accusations were in all probability true.

I05. The Weekly Gazette, 8 January I9I4; ibid., I6 March I9I4. No circulation figures for this paper could be ascertained.

I06. Ibid., 9 January I9I4. 


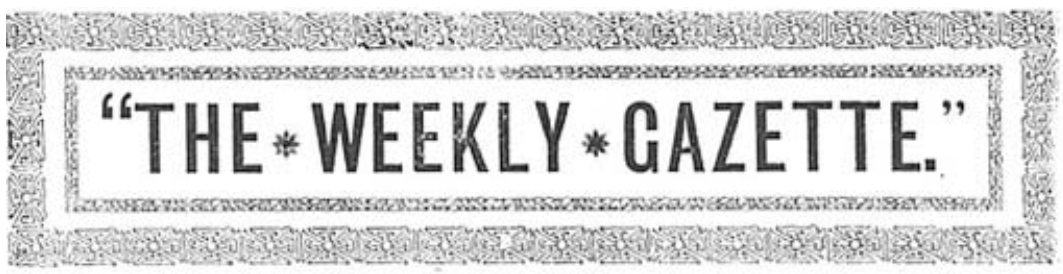

THE WORKERS PAPER.

\section{Special "Strike" Daily Edition.}

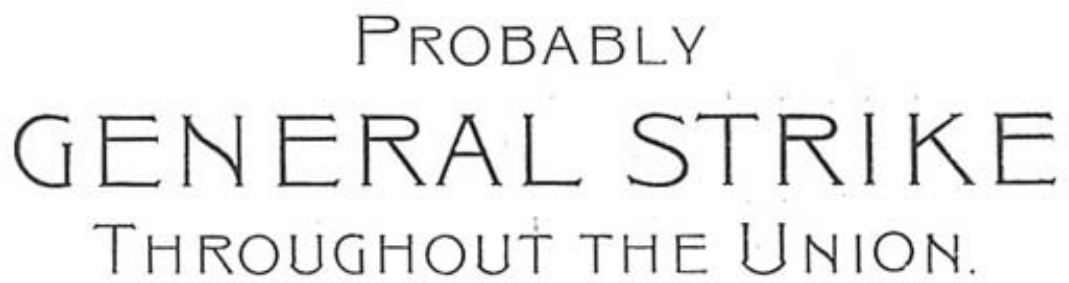

\section{ALL WORKERS MUST BE PREPARED TO OBEY THE CALL TO "DOWN TOOLS" THE MOMENT THE CALL IS MADE.}

From reliable information just gained we are in a position to state that the Transvaal Miners' Assosiation and Federation of Trades will proclaim a GENERAL STRIKE throughout the Union at their Meeting to-night.

Watch our Extra Special to-night.

Figure 3. A copy of The Weekly Gazette "special Strike daily edition", January I9I4.

conduct was criticized, and the paper stated that the strikers were against the use of violence. Although the Gazette strongly denounced the use of scab labour, it also admonished the workers to refrain from the use of violence. ${ }^{107}$

The daily strike edition of The Weekly Gazette appeared on Wednesday I 4 January I9I 4 for the last time. The editor declared that, owing to the proclamation of martial law, the editorial staff was unable to offer any criticism on the strike situation. Therefore, they were unable to publish 
certain items. On 26 January, Horak was charged with contravening Regulation 5 of martial law stipulations, the allegation being that on Is January he "wrongfully and unlawfully printed, published or circulated a pamphlet, leaflet or other document containing words or information calculated to promote disaffection or excite ill-feeling". Eventually he was discharged, and the weekly publication of the Gazette was resumed on I6 March I9I $4 .{ }^{\text {I08 }}$

The Pretoria branch of SATU decided to assist in the production of a strike newspaper, and proposed that unemployed SATU members be used. I.L. Walker, the branch secretary, was the editor. A printing plant was rented from P. Miles and Company in Du Toit Street, Pretoria. The short-lived Pretoria Strike Herald, a single-page broadsheet that appeared on I7 January I9I4, was distributed free of charge. The first impression produced 10,000 copies, and there was allegedly a great demand for more. The Herald contained items on trade-union resolutions regarding the strike, and general strike news, as well as news on the surrender of the strike leaders in the Fordsburg Trades Hall. ${ }^{109}$ Mindful of the falsehoods and distortions of press reporting by the capitalist press on the actual strike situation, the Herald induced the workers to remain on strike. ${ }^{\text {Io }}$

However, after the appearance of the first edition the police raided the Pretoria Strike Herald's printing plant. P. Miles, the owner, and four compositors were arrested on the premises, and, like Horak of The Weekly Gazette, charged under martial law with printing matter "calculated to promote disaffection or excite ill-feeling". They were also charged with contravening martial law regulations, because the Herald allegedly stated prematurely that the government's citizen forces were going to be demobilized. During the raid, the police confiscated and broke all the printing-forms and galleys for the type already set for the second edition of the Pretoria Strike Herald, scheduled for i 8 January i9i4. A few days later, Walker, the editor, was also arrested and charged under martial law with sedition. Eventually the leaflet's printing staff were fined amounts ranging between $£_{20}$ and $£_{2} 5$, while Walker was sentenced to imprisonment for one month, without the option, on one charge, and fined $£_{25}$ or one month on another. ${ }^{\text {III }}$

108. Cd., 7348-ı14, pp. I26, I75; The Weekly Gazette, I4 January 1914; ibid., I6 March I9I4.

I09. Cd., 7348-1914, pp. I35, I51; Walker and Weinbren, 2000 Casualties, p. 50; Downes, Printers' Saga, pp. 397-398; Pretoria Strike Herald, I7 January 1914; ibid., I 8 January I9I 4. I I0. Pretoria Strike Herald, I7 January I9I4. See also ibid., I 8 January I 9 I 4, and nn. I 26 and I 27 above.

I I r. Cd., 7348-1914, pp. I35-184; Walker and Weinbren, 2000 Casualties, pp. 50-51; Downes, Printers' Saga, pp. 397-400; Pretoria Strike Herald, i 8 January i9I4. 


\section{PRO-STRIKE PRESS RESPONSES TO THE I 922 RAND REVOLT}

The white labour movement emerged from the strikes of I9I 3 and I9I4 still militant and relatively strong. ${ }^{I 2}$ But the year 1922 saw the biggest and bloodiest industrial upheaval in South African labour history, which took on the appearance of a civil war on the Witwatersrand. This strike, which was characterized by pitched battles between armed forces of labour and the state, was initiated by a worldwide depression towards the end of I 920 , causing the price of gold to drop in I92 I. The wage bill was the one area in which costs could be cut to meet rising expenditure, and this in turn made semiskilled employment the most sensitive issue, because blacks and whites were both commonly employed in this field. In November I92 I, in the face of the growing economic crisis, the Chamber of Mines gave notice of its intention to abandon the status quo agreement by eliminating a colour bar that protected white labour in any semiskilled job.

Wage negotiations between the South African Industrial Federation, or SAIF, (founded in the wake of the I9I4 general strike) and the Chamber repeatedly broke down. In January I922, a militant miners' Council of Action was formed, that would push the wage issue to extreme levels with revolutionary intent. Coalminers, as well as goldminers, engineers, and power workers, came out on strike on 2 January and io January, consecutively. Eventually the revolutionary Council of Action seized the initiative, and forced the SAIF to proclaim a general strike on 7 March I922, when 22,000 white workers were on strike. Some strike commandos brandished banners that proclaimed "Workers of the World Fight and Unite for a White South Africa". ${ }^{113}$ By that time, violence had already broken out and acts of sabotage been committed. When law and order collapsed, General J.C. Smuts, then Prime Minister, proclaimed martial law on Io March 1922. Units of the Active Citizen Force and Citizen Reserve were also mobilized. The climax of the fighting took place in Fordsburg, Johannesburg, where strikers were entrenched in the Trades Hall. When the strike headquarters were overrun by government troops, two extremist strike leaders, Percy Fisher and Harry Spendiff, refused to surrender and committed suicide. On 17 March 1922 the trade unions called off the strike. ${ }^{\text {I } 4}$

I 12. See Walker and Weinbren, 2000 Casualties, pp. 32-44, 47-58; D. Yudelman, The Emergence of Modern South Africa: State, Capital and the Incorporation of Organized Labor on the South African Gold Fields, 1902-1939 (Westport, CT, 1983), pp. 93-1 I2; R.H. Davies, Capital, State and White Labour in South Africa I900-I960 (New Jersey, I979), pp. 80-8 I, I 20I 23 .

I I3. A.G. Oberholster, Die Mynwerkerstaking Witwatersrand, 1922 (Pretoria, I982), p. I4I; W. Urquhart, The Outbreak on the Witwatersrand March 1922 (Johannesburg, 1922), p. 33.

I I4. See T.R.H. Davenport, South Africa: A Modern History (Johannesburg, 1987), pp. 279- 
In order to understand the militant anticapitalist class antagonism of the white labour movement at the time, as reflected by pro-strike newspapers such as The International, it is necessary to examine the concept of "White South Africa" more closely.

In the light of Hyslop's views on the white socialist fusion of class and racial consciousness, Krikler argues that the interests of a "White South Africa" were bound up with the interests of the white working class, which launched an offensive upon the bourgeoisie and the government that protected its own interests. White working-class identity and community were perceived to be under the most profound threat, as if their claim to a place within "White South Africa" was being denied by the government and the employers. I922 was a time when a highly developed classconsciousness jostled with racial notions and ideologies, in a movement that linked racial privileges for white workers with a campaign against capitalist prerogatives. Central to this notion was not only the racial component for which the strikers fought, but also for a dispensation in which white labour would have a special claim, where it would be protected from the cost-cutting operations of capital. ${ }^{\text {II }}$

In a more recent article, Krikler explored further the notion of white working-class identity. He argued that the term "White South Africa" denoted a particular organization of state, society, and economy, one in which the white workers would be guaranteed protection against the immiserating tendencies of capitalism. For the strikers, it meant refusing the right of employers to dictate terms to organized labour, because in I 922 one of the core elements of white workers' identity was their feeling that they were once again the subjects of an industrial despotism. Fundamental to white working-class identity, Krikler argues, was the feeling among the white workers that they were not really citizens of the South African state. These workers wanted a different state, a "White South Africa" that fully respected the white workers and gave them real and effective rights - in essence the right of white workers not to be dictated to, but to be considered part of the citizenry. ${ }^{116}$

Such sentiments were echoed in the pro-strike press as early as the I9I 3 strike. Reflecting upon the strike, The Worker stated:

282; Oberholster, Die Mynwerkerstaking Witwatersrand, I922, pp. 56-191; Urquhart, The Outbreak on the Witwatersrand March 1922, pp. 74-96; UG, 35-1922, pp. I-74. The 1922 general strike took a heavy toll on human lives. The official figures are that 43 soldiers, 86 policemen, and 8 I civilians were killed, while I 33 soldiers, 86 policemen, and 3 I 5 civilians were wounded in the skirmishes. During and after the strike, 4,692 persons were arrested, and 853 were tried on charges of murder, high treason, and transgression of martial law regulations. Eventually, 4 were hanged. The rest were sentenced to between 6 months and life imprisonment. i I 5. J. Krikler, "The Commandos: The Army of White Labour in South Africa", Past and Present, I63 (1999), pp. $205,207$.

i 16. Krikler, "White Working Class Identity and the Rand Revolt", pp. 21-22, 28, 30. 
[...] a white worker [...] claims in this country, as he has long claimed elsewhere, to be recognised and treated not with the "contemptuous intolerance" shown by a "baas" to a "boy", but as a man and a citizen whose right to life, liberty and competence is as important as his "master's". ${ }^{117}$

As its editor, W.H. Andrews, was a prominent member of the Council of Action, The International, organ of the Communist Party of South Africa (CPSA) became intimately involved with the strike. ${ }^{\text {I8 }}$ Already, in February I920, the paper had prophetically predicted an imminent general strike of revolutionary proportions on the Witwatersrand. ${ }^{\text {I9 }}$ Therefore, the communists welcomed the great upheaval of I922. They believed that it was the start of a revolution that would unseat the ruling class and usher in an ideal socialist commonwealth. ${ }^{\mathrm{I} 20}$

Already, in December I92 I, Andrews had welcomed, through his paper, the white miners' rejection of any wage reduction and encouraged the executive of the miners' union to call a strike. ${ }^{\text {I I }}$ However, as Hyslop has noted, white South African socialists held ambiguous views on racism and egalitarianism, so also white communists' attitudes implied that white wage standards should be protected from falling to black wage levels. Andrews reasoned that capitalism would reduce white workers' remuneration to black workers' wage levels, and thus force both groups to recognize their class interests. Interracial solidarity would grow out of the class struggle, because security for the white man lay not in retaining the colour bar, but in raising the wages of black workers to white standards. As capitalism offered no hope for either black or white workers, equality including wage equality - could be realized after the revolution (strike) and the subsequent destruction of capitalism. ${ }^{\text {I22 }}$

The International urged an expansion of the strike to enhance the workers' bargaining position and Andrews condemned all attempts at

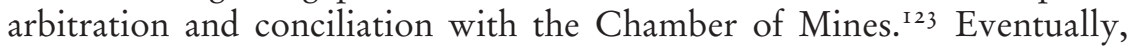

I 17. The Worker, i7 July i9i3, p. I. In the South African context, the term "baas" refers to a boss, and "boy" to an African worker.

I 1 8. Cope, Comrade Bill, p. 249; Simons and Simons, Class and Colour, pp. 26I, 299. The CPSA was founded in July I92 I. According to police reports, 5,000 copies of this weekly were printed by October 1920, of which a considerable number were posted to black addressees. See CAD, JUS vol. 267, file no. 3/1064/18, Reports on Bolshevism in South Africa: Commissioner South African Police to Secretary for Justice, 27 August 1920, p. 5; ibid., 30 October 1920, p. 56.

I 19. The International, 6 February 1920, p. 2.

I20. Simons and Simons, Class and Colour, p. 270.

I 2 I. The International, 30 December i 921 , p. I.

I22. Simons and Simons, Class and Colour, pp. 270, 281, 285 , 289-290; Johns, Raising the Red Flag, pp. I35, I44-I45. See also The International, I3 January 1922-24 February 1922. Andrews's paternalist reasoning, that black and white wage equality would only be realized if black wages would be raised to white standards, confirms Hyslop's views on white labourism. I23. Johns, Raising the Red Flag, p. I34; The International, I 8 February I92 I, p. 2; ibid., I 3 January I922, pp. I, 2; ibid., 20 January I922, p. 2; ibid., 27 January 1922, p. I. 
Andrew's antagonistic editorials caught up with him. On I4 February 1922 he was arrested on a charge of incitement to violence, but was later released on bail. In his absence Sidney Bunting acted as editor. ${ }^{\mathrm{I} 4}$ Indeed, the longer the duration of the strike, the more militant The International's message to the strikers became. In the issue of 3 March 1922, the last to appear for almost three months, The International criticized the government's intervention in the strike on the side of mining capital, and hinted at a workers' seizure of the mining industry. ${ }^{\mathrm{I} 25}$

It came as no surprise, therefore, when the government, after the proclamation of martial law, swooped on the offices of the CPSA in the Trades Hall in Fordsburg. The police confiscated documents, books, and pamphlets, and the CPSA's press was damaged beyond repair. W.H. Andrews and S.P. Bunting were arrested and held in the Johannesburg Fort for the remainder of the strike. For ten weeks, from the beginning of March until the end of May i922, The International was suppressed by the authorities. Andrews and Bunting were eventually released and acquitted of a charge of public violence. ${ }^{\mathrm{I} 26}$

As with the strikes discussed earlier, a strike publication appeared in the course of the 1922 strike. On I 3 February 1922 the first issue appeared of a so-called "strike paper", the Transvaal Post, edited by W.F. Mondriaan, a Dutchman who became a naturalized citizen of Paul Kruger's South African Republic. ${ }^{\mathrm{I} 7}$ At that time, there was a great need among both supporters of the Afrikaner-based Nationalist Party (NP) and the Englishspeaking SALP for a newspaper that would reflect the thoughts and aspirations of the white working class on the Witwatersrand, which were ignored or distorted by the capitalist press. After negotiations with prominent Labour leaders, Mondriaan agreed to publish a bilingual daily which would advocate the viewpoints of both the NP and the SALP. ${ }^{28}$ The Transvaal Post, with the subtitle "the champion of an economically free South Africa", was published in Pretoria and sold at $2 \mathrm{~d}$ per copy.

For the Transvaal Post, the cardinal issue was the clarion call for a "white South Africa" by the strikers. Therefore, it implied that the preservation of the colour bar in the mining industry was the "only solution" to the strike. Smuts and the Chamber of Mines were severely

I24. Cope, Comrade Bill, pp. 249-250; The International, i7 February I922, pp. I-2; ibid., 24 February 1922, p. I.

I 25. The International, 3 March I922, pp. I-2.

I26. Cope, Comrade Bill, pp. 276, 278, 28 I, 283; E. Roux, S.P. Bunting: A Political Biography (Bellville, I993), p. 35; The International, 26 May I922, pp. 2, 3; ibid., 9 June 1922, p. I.

I27. Transvaal Post, I 3 February 1922. I could trace only two copies of this publication in the Johannesburg Public Library.

I28. South African National Defence Force Archives, Pretoria [hereafter, SANDFA], W.F. Mondriaan, "Herinneringe en ervaringe deur my persoonlik beleef in 'n 'Halwe eeu van onreg'", deel 2, Die opstand aan die Rand (I922), pp. 7-I2. 
denounced for their support for the abolition of the colour bar. The paper's columns contained speeches by Labour and strike leaders, lists of food distribution depots for strikers, and strike committees, as well as dates and meeting places where strike distress funds were being collected. The Transvaal Post also published general items on strike events and meetings, snippets of international news, and cartoons on strike issues. ${ }^{29}$ As it provided strike news and support for the strike, the Transvaal Post became immensely popular with the white working class on the Witwatersrand. The first edition sold 8,000 copies and Mondriaan claimed that, when the paper was at its peak, it sold 26,000 copies daily. To meet the demand, day and night shifts were introduced at the printing plant and therefore some compositors slept on the premises. ${ }^{130}$

As a result of the proclamation of martial law on Io March I922, publication of the Transvaal Post was prohibited, and the police raided its offices and printing plant. Apparently, the government regarded its contents as being revolutionary and seditious. Mondriaan, the editor, was arrested and detained in Johannesburg. After he was released on bail, he fled to Mozambique, where he was also temporarily incarcerated, as he was accused of being an illegal immigrant. After three months, when martial law was repealed, Mondriaan returned to Pretoria. However, in his absence, the Transvaal Post went bankrupt and would never appear again. ${ }^{3}{ }^{3}$

\section{CONCLUSION}

Despite their anticapitalist rhetoric and pro-worker bias, strike papers can, in general, be regarded as a reliable historical source, as they provide a unique and intimate insight into the rationale of worker behaviour during strike action. They also provide important clues as to what workers think about their role and place in times of industrial strife. An important proviso, though, is that such sources should always be interpreted within the context of the specific labour conditions under which they were produced.

Therefore a central question regarding the pro-strike press in early twentieth-century South Africa is the extent to which these publications influenced and impacted upon strike action. O'Quighley has observed that the strict press censorship introduced during most of the strikes limits proper assessments of strike tendencies. Also, the available research

I29. See Transvaal Post, I3 February 1922 and I 8 February 1922.

I30. SANDFA, Mondriaan, "Herinneringe en ervaringe", pp. I3-15, 22; Transvaal Post, I3

February I922.

I 3 I. SANDFA, Mondriaan, "Herinneringe en ervaringe", pp. 23, 66-67. 
material on the early South African labour press in general, and pro-strike publications in particular, does not provide circulation figures, and there are few preserved sets of newspaper copies. Nor do published labour histories, trade-union documents, and memoirs of labour and socialist personalities provide adequate solutions to this problem. Government publications and documents justify the suppression of pro-strike literature only in very vague and almost cursory terms, and concentrate instead on analysing the causes and consequences of industrial upheavals.

In a negative sense, it could be argued that the labour movement lacked the determination, but mostly the financial capacity, to sustain pro-strike papers and turn them into successful commercial enterprises. Relatively speaking, their readership base was narrow, and circulation figures remained low and confined largely to a small group of socialists, or even exclusively to trade-union members. In addition, none of the strike papers and sheets was preemptive in terms of instigating strikes. Rather, they were initiated as a result of the outbreak of industrial strife to further the strikers' cause, and to serve as vital conduits of striker communication. In that sense, these papers reflected the strikers' consciousness rather than formed it.

However, the fact that these papers only came into existence after a strike started does not mean that they did not have a strong influence on maintaining the morale of the strikers, expanding support for the strike and spreading new political ideas. The government's suppression of prostrike literature during the industrial upheavals of I9I4 and I922 - for example, The Worker, The Weekly Gazette, the Pretoria Strike Herald, The International, and the Transvaal Post - suggests that the presence of these publications and their influence on the strike mood must, at least, have unnerved the authorities. In the I9I4 strike, where, according to estimates, the total number of strikers was considerably less than the I9,000 of the I9I 3 strike, The Worker still published approximately 2,000 copies and the Pretoria Strike Herald I0,000. At the height of the 1922 strike, when 22,000 white workers were out, The International enjoyed a circulation of 5,000 and the Transvaal Post 26,000. Clearly therefore, the government perceived these papers as contributing to prolonging the strikes or threatening public order which, as a result, led to their suppression and closure under martial law.

Indeed, the violent and militant nature of the strikes of I9I3 and I9I4 made an indecisive government realize that, in an industrial society, state intervention and legislative enactment were necessary for the protection and welfare, not only of its industrial workers, but also of private enterprise and the state itself. ${ }^{12}$ According to Yudelman, state interven- 
tion (with measures such as martial law and its implications for the prostrike press) became more severe in the 1922 strike, and led to the final subjugation of organized white labour. For Yudelman, there is no doubt that the increased role of the state did bring a virtual end to militant whiteworker resistance. ${ }^{\mathrm{I} 33}$

As was explained earlier, strike action became a global phenomenon in the early twentieth century. Thus, although pro-strike newspapers such as Voice of Labour, The Worker, and The International cannot be regarded as actual strike publications, they were instrumental in fostering a militant climate among the white working class conducive to the use of the strike weapon in industrial disputes. In a very important way, these papers also reflected the general militant, anticapitalist class antagonism and mood of unrest that permeated the white labour movement prior to the major strikes of that period.

An outstanding feature of the period under discussion was the pivotal position of the pro-strike and numerically strong and influential SATU, especially in times of industrial strife. As Ruud has illustrated, a welldeveloped printing tradition, printing-union fraternity, and printing industry are highly conducive to the emergence of a pro-strike press. What makes this even more significant, in the case of SATU, is the fact that this union was not engaged in a dispute over its own terms and conditions of employment in the strikes of I9I3, I9I4, and I922, but was acting purely in sympathy with the miners and the Federation. In doing so, union branches and individual members, who were in relative abundance, also initiated actual strike papers. Furthermore, the majority of compositors, machinists, and typesetters involved in the production of all other prostrike publications discussed in this article were also SATU members.

But most of all, the pro-strike literature of early twentieth-century South Africa reflects in essence a "white-labour" discourse. Hyslop has shown that, based on the imperial working-class's common ideology of "white labourism", and influenced by strong traditional links to the labour movement of the British Empire, a fusion of class and racial consciousness occurred among the white working class of South Africa. Such sentiments were echoed by pro-strike socialist newspapers, such as Voice of Labour and The International. And the wide circulation of British labour and socialist literature locally enhanced the South African white working class's awareness of the efficacy of strike action to defend their rights. In the light of Hyslop's views, Krikler argued that fundamental to white working-class identity was white labour's agitation for the right not to be dictated to, but to be considered part of the citizenry. It is within this context, together with the structurally insecure position of the white proletariat vis-à-vis cheaper, capitalist-exploited black labour, that pro-

I33. Ibid., pp. 164-186, 233. 
strike publications in early twentieth-century South Africa purported "to fight the battles of the [white] workers".

Given the wealth of information on the history of the local labour movement, the South African labour and socialist press is an important research field that can still be extensively exploited by labour historians and sociologists to construe the discourse of white workers on race and class-consciousness. 